\title{
Experimental Investigation of Sulfuric Acid Condensation and Corrosion Rate in Motored Bukh DV24 Diesel Engine
}

Kjemtrup, Lars; Cordtz, Rasmus Faurskov; Meyer, Martin ; Schramm, Jesper

Published in:

Proceedings of the ASME 2017 Internal Combustion Engine Division Fall Technical Conference

Link to article, DOI:

10.1115/ICEF2017-3652

Publication date:

2017

Document Version

Peer reviewed version

Link back to DTU Orbit

Citation (APA):

Kjemtrup, L., Cordtz, R. F., Meyer, M., \& Schramm, J. (2017). Experimental Investigation of Sulfuric Acid Condensation and Corrosion Rate in Motored Bukh DV24 Diesel Engine. In Proceedings of the ASME 2017 Internal Combustion Engine Division Fall Technical Conference [ICEF2017-3652] American Society of Mechanical Engineers. https://doi.org/10.1115/ICEF2017-3652

\section{General rights}

Copyright and moral rights for the publications made accessible in the public portal are retained by the authors and/or other copyright owners and it is a condition of accessing publications that users recognise and abide by the legal requirements associated with these rights.

- Users may download and print one copy of any publication from the public portal for the purpose of private study or research.

- You may not further distribute the material or use it for any profit-making activity or commercial gain

- You may freely distribute the URL identifying the publication in the public portal 


\section{EXPERIMENTAL INVESTIGATION OF SULFURIC ACID CONDENSATION AND CORROSION RATE IN MOTORED BUKH DV24 DIESEL ENGINE}

\author{
Lars Kjemtrup* \\ PhD Student, Thermal Energy Section \\ Department of Mechanical Engineering \\ Technical University of Denmark \\ Kgs. Lyngby, Denmark \\ Email: larskj@mek.dtu.dk \\ Martin Meyer \\ MSc Student, Thermal Energy Section \\ Department of Mechanical Engineering \\ Technical University of Denmark \\ Kgs. Lyngby, Denmark
}

\author{
Rasmus Faurskov Cordtz \\ Researcher, Thermal Energy Section \\ Department of Mechanical Engineering \\ Technical University of Denmark \\ Kgs. Lyngby, Denmark
}

\author{
Jesper Schramm \\ Professor, Thermal Energy Section \\ Department of Mechanical Engineering \\ Technical University of Denmark \\ Kgs. Lyngby, Denmark
}

\section{ABSTRACT}

The work conducted in this paper presents a novel experimental setup to study sulfuric acid cold corrosion of cylinder liners in large two-stroke marine diesel engines. The process is simulated in a motored light duty BUKH DV24 diesel engine where the charge air contain known amounts of $\mathrm{H}_{2} \mathrm{SO}_{4}$ and $\mathrm{H}_{2} \mathrm{O}$ vapor.

Liner corrosion is measured as iron accumulation in the lube oil. Similarly sulfuric acid condensation is assessed by measuring the accumulation of sulfur in the lube oil. To clarify the corrosive effect of sulfuric acid the lube oil utilized for experiments is a sulfur free neutral oil without alkaline additives (Chevron Neutral Oil 600R).

Iron and sulfur accumulation in the lube oil is analyzed with an Energy Dispersive X-Ray Fluorescence (ED-XRF) apparatus. Three test cases with different $\mathrm{H}_{2} \mathrm{SO}_{4}$ concentrations are run. Results reveal good agreement between sulfuric acid injection flow and the accumulation of both iron and sulfur in the oil.

\section{INTRODUCTION}

Shipping of goods and bulk products etc. in large vessels across the world is an important business where medium- or low-

*Address all correspondence to this author. speed engines are used for powering most of these. Low-speed two-stroke diesel engines are often fueled with Heavy Fuel Oil (HFO) that may contain up to $3.5 \% \mathrm{~m} / \mathrm{m}$ sulfur [1].

During combustion the fuel sulfur is oxidized primarily to gaseous sulfur dioxide $\left(\mathrm{SO}_{2}\right)$ from which a fraction is subsequently converted to sulfur trioxide $\left(\mathrm{SO}_{3}\right)$. Experimental investigations of diesel exhausts [2,3] and theoretical work [4] show that depending on the operating conditions $1-8 \%$ of the fuel sulfur is converted to $\mathrm{SO}_{3}$ in the cylinder gas. Both $\mathrm{SO}_{2}$ and $\mathrm{SO}_{3}$ can combine with water vapor formed during combustion forming corrosive gaseous sulfurous acid $\left(\mathrm{H}_{2} \mathrm{SO}_{3}\right)$ and sulfuric acid $\left(\mathrm{H}_{2} \mathrm{SO}_{4}\right)$ respectively [5]. Modelling work and experimental investigations reveal up to approximately $30 \mathrm{ppm}$ sulfuric acid in the combustion gas of marine diesel engines [2,6]. The acid components can condense and lead to corrosion of important internal engine components such as the cylinder liner. The phenomenon is called cold corrosion and condensation takes place if the surface temperature is lower than the dew point of the acid $[7,8]$.

Cold corrosion has shown to be of real concern especially in the latter years and becomes more pronounced due to the principle of slow steaming (low load operation) that has pushed the engines even further to the extreme regarding temperature and pressure. Similar change in operating conditions was observed during the oil crisis in the 1970's [9]. When engines are operat-

Post Print 
ing at part load, temperatures inside the combustion chamber become favorable for condensation of sulfuric acid on the liner surface, which may lead to deviating cold corrosion behaviour [10].

Abnormal corrosion is undesired, whereas a slight "controllable" corrosion rate of cylinder liner surfaces are desired in order to maintain a sufficiently rough liner surface for supporting an oil film $[11,12]$. If cold corrosion takes place for prolonged periods of time the surface of cylinder liners and piston rings loses integrity leading to particles, severe abrasion and utimately adhesive wear or scuffing [13].

To hamper corrosion the Cylinder Lubrication Oil (CLO) of large two-stroke marine engines contain base additives that is used for neutralizing condensed acid. However, earlier lubrication oil strategies only take fuel sulfur content and engine load into consideration [14]. It is difficult to measure corrosion of the liner online and relate it to the operating conditions. This paper describes a novel test facility where cold corrosion can be simulated, subsequently measured and related to cylinder gas properties (operating conditions) and surface temperature. For the purpose a motored light duty (BUKH DV24) diesel engine is used where the lube oil system is modified to accelerate test time. The level of corrosion is measured as iron $(\mathrm{Fe})$ accumulation in the lube oil swamp. Additionally insights into sulfuric acid condensation will be presented.

The current research project is a part of the SULCOR project funded by Innovation Fund Denmark. The project is managed by DTU Mechanical Engineering in collaboration with DTU Chemical Engineering and MAN Diesel \& Turbo.

\section{METHOD}

\section{Experimental Setup}

The experiments are conducted on a modified BUKH DV24 four-stroke diesel engine, see Fig. 2. A schematical setup of the test rig can be seen in Fig. 1. The engine is motored by an electric AC motor via a 1:15 worm gear. The speed is held at $98 \mathrm{rpm}$ (controlled by a frequency converter) in order to match the speed in a large two-stoke engine and chemical time scales of sulfuric acid condensation and corrosion. General engine specifications are shown in Tab. 1.

Pressurized charge air is heated using a ceramic heater. Subsequently a diluted sulfuric acid mixture is dosed into the hot air (using a peristaltic pump) and evaporates. By keeping a constant flow of air and diluted acid a hot homogeneous charge of air and $\mathrm{H}_{2} \mathrm{O}+\mathrm{H}_{2} \mathrm{SO}_{4}$ vapor is produced. At the engine intake valve the charge temperature is around $160-190{ }^{\circ} \mathrm{C}$ and above the sulfuric acid dew point to avoid any condensation before the engine cylinder. The intention of the conditioning is to supply the motored engine with quantities of evaporated water and sulfuric acid that simulates the real conditions within a marine diesel engine. Depending on the injection flow rate and concentration of the diluted acid mixture, the concentration and thereby the partial pres-
TABLE 1. TECHNICAL MAIN DATA FOR BUKH DV24

\begin{tabular}{lc}
\hline Parameter: & Value: \\
\hline Working Principle & 4-stroke \\
No. of Cylinders & 2 \\
Bore and Stroke & $85 \mathrm{~mm}$ \\
Conrod Length & $159.8 \mathrm{~mm}$ \\
Swept Volume & $964 \mathrm{~cm}^{3}$ \\
Compression Ratio & $18.5: 1$ \\
IVO & 32 CAD BTDC \\
IVC & 64 CAD ABDC \\
EVO & 64 CAD BBDC \\
EVC & 32 CAD ATDC \\
\hline
\end{tabular}

sures of $\mathrm{H}_{2} \mathrm{O}$ and $\mathrm{H}_{2} \mathrm{SO}_{4}$ of the cylinder gas can be determined during compression and expansion.

Ethylene glycol is circulated through the cooling channel and around the cylinder liners in order to control the liner surface temperature and match it according to large marine engines. 8 thermocouples are installed in each cylinder liner, $1 \mathrm{~mm}$ from the surface, to measure the temperatures in the top, middle and bottom of the piston stroke. In one cylinder two thermocouples are placed at the top of cylinder liner, four in the middle and two at the bottom. The other cylinder has four thermocouples placed at the top, two placed in the middle and two at the bottom. The thermocouples are calibrated within $\pm 1{ }^{\circ} \mathrm{C}$ at $100{ }^{\circ} \mathrm{C}$.

Lubrication Oil System. The original oil pump that is driven by the camshaft is replaced for optimum control of dosing of lube oil. The modified oil system is made independent of engine speed. A high pressure Danfoss BFP 21 L3 pump provides oil at approximately 15 bar for two spray nozzles (Danfoss fuel oil nozzles). The nozzles are positioned in the base cover below the cylinders, see Fig. 3, and supply oil for liners and piston rings. A low pressure Scherzinger 51 FBR/GM005 pump provide oil at 1-3 bar for the crankshaft, main bearings and connecting rod bearings. Both pumps extract oil from the oil reservoir, a $600 \mathrm{~mL}$ beaker, below the engine base cover, see Fig. 4. The beaker is placed on a magnetic stirrer with $400 \mathrm{~W}$ heating. In addition to the lube oil nozzles a milled channel for oil drainage is seen going to the drain hole, leading to the oil beaker. The oil system is of high importance during testing since it facilitates the possibility to extract $5 \mathrm{~mL}$ test samples through a valve that is connected to the low pressure oil system, as shown in Fig. 2. 


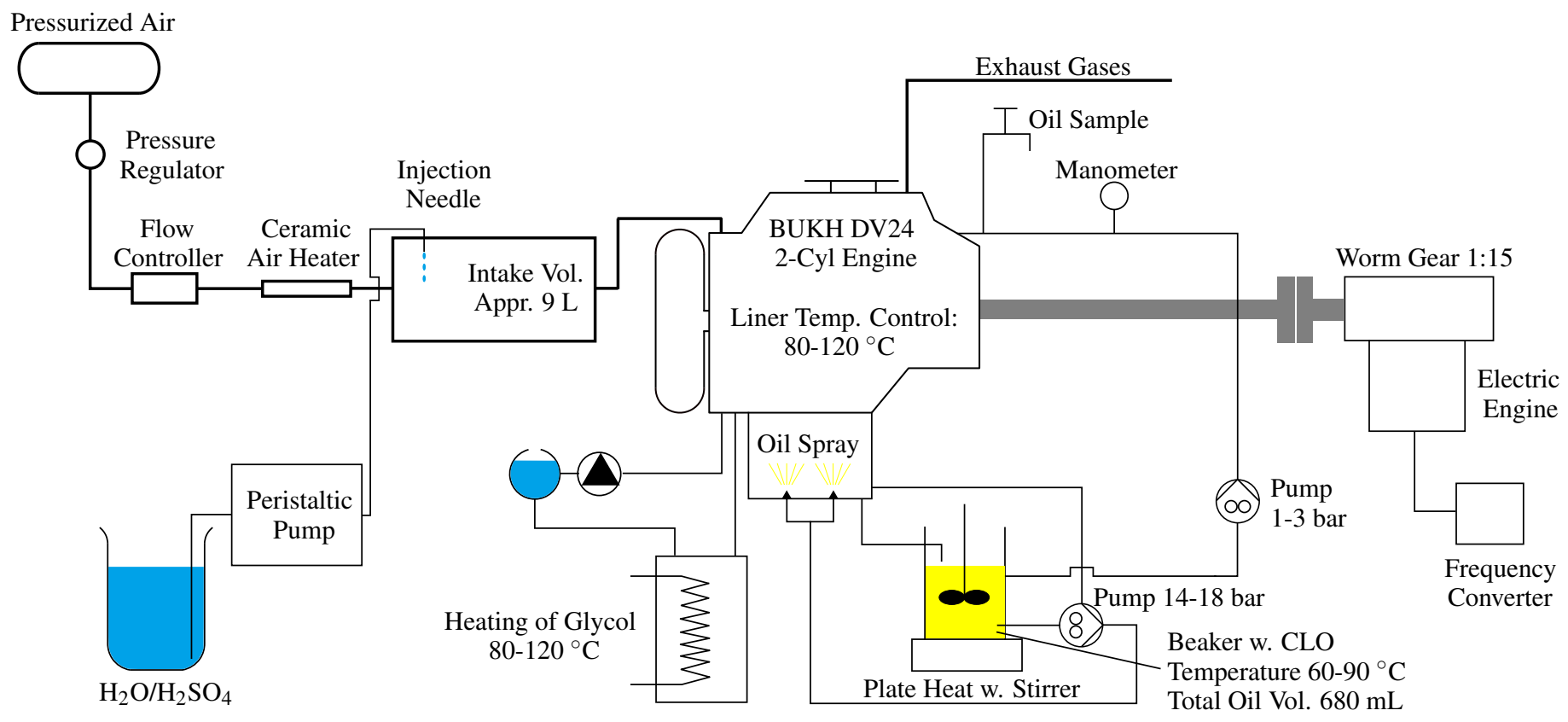

FIGURE 1. SCHEMATICAL SETUP OF COLD CORROSION TEST RIG USING A BUKH DV24.

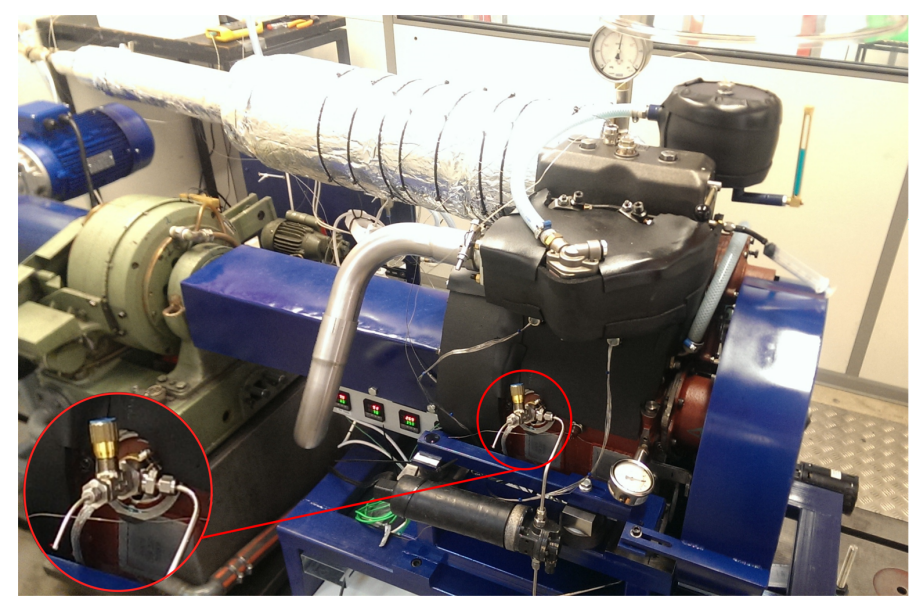

FIGURE 2. BUKH DV24 TEST ENGINE, MODIFIED FOR MOTORED EXPERIMENTS AT 98 RPM. THE VALVE MARKED WITH RED CIRCLE IS USED FOR EXTRACTING OIL DURING A TEST.

Regular CLO normally contain approximately $10,000 \mathrm{mg} / \mathrm{kg}$ sulfur when formulated for use in marine engines. This makes it difficult to identify relative changes in sulfur concentration during testing. Due to the high sulfur content in conventional marine engine CLO an alternative sulfur free base oil is used. The oil utilized for investigating the corrosion and sulfuric acid condensation rate is Chevron Neutral Oil 600R, see Tab. 2 for properties.

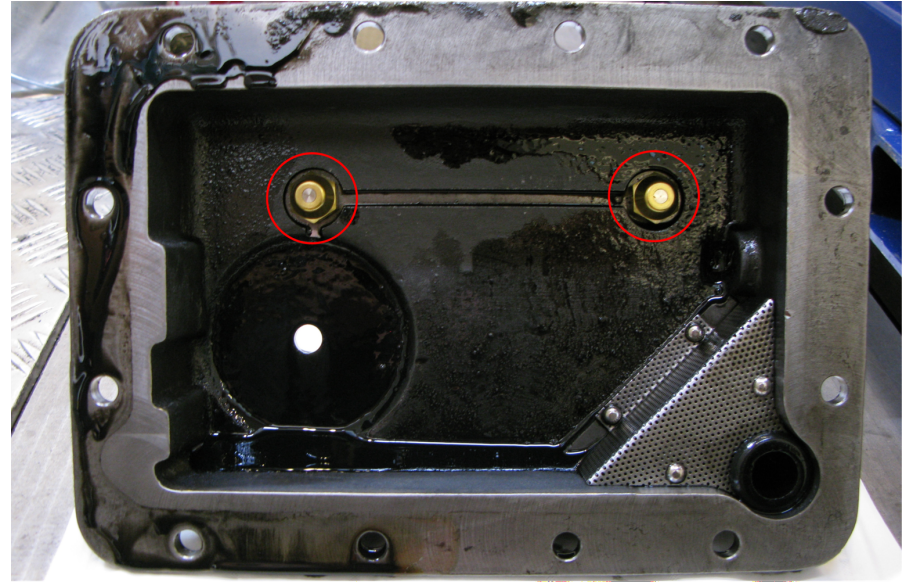

FIGURE 3. DANFOSS FUEL OIL NOZZLES INSTALLED IN BASE COVER MARKED WITH RED CIRCLES.

ED-XRF Analysis Collected lube oil samples are analyzed for their elemental composition using an Energy Dispersive X-Ray Fluorescence (ED-XRF) apparatus. The ED-XRF technique is a standard (ASTM D7751-16) for determination of additive elements in lube oils and rely on ionizing radiation from X-Rays

The species of interest are primarily iron (Fe) and sulfur (S), measured down to $2 \mathrm{ppm}$ with a statistical precision of $\pm 1 \%$. The apparatus used in the present study is an AMETEK SPECTRO XEPOS XRF that is designed for industrial use. 


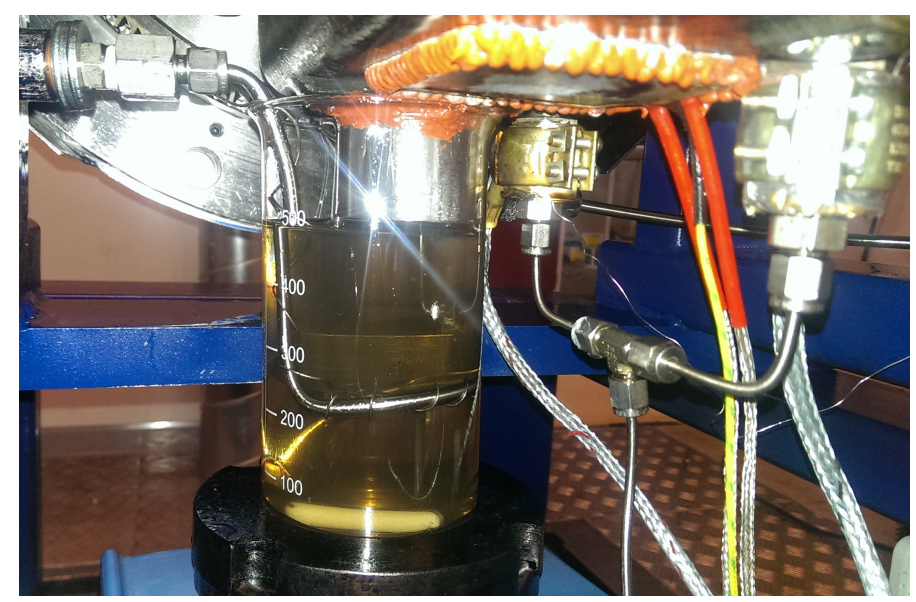

FIGURE 4. LUBRICATION OIL RESERVOIR. NOZZLE RINGHEATERS AND A $220 \mathrm{~W}$ PLATE HEATER IS SEEN IN TOP RIGHT CORNER.

TABLE 2. PROPERTIES FOR CHEVRON 600R BASE OIL.

\begin{tabular}{lc}
\hline Parameter: & Value: \\
\hline Appearance @ 23.9 ${ }^{\circ} \mathrm{C}$ & Bright and clear \\
Density @ 15.6 ${ }^{\circ} \mathrm{C}$ & $0.867 \mathrm{~g} / \mathrm{cm}^{3}$ \\
Viscosity@ $@ 4{ }^{\circ} \mathrm{C}$ & $102 \mathrm{cSt}$ \\
Viscosity @ 100 ${ }^{\circ} \mathrm{C}$ & $12.0 \mathrm{cSt}$ \\
Sulfur Content & $<6 \mathrm{ppm}$ \\
\hline
\end{tabular}

It is calibrated using different preformulated oils with different compositions of several species. The XRF is ideal for analysis of 24 elements in petrochemical products, e.g. additive packages in lubrication oils, used oils, crude oil distillates and especially for sulfur in HFO.

Test Schedule The preliminary testing conducted on the engine is intended to demonstrate the capabilities of the experimental test rig. Three different 5-6 hour experiments are conducted. The intake air composition can be seen for the three Test Cases (TC) in Tab. 3. The compositions are based on mass balance of the species supplied to the engine, measured by air flow meter and the mass consumption of the diluted sulfuric acid. Each test starts with $680 \mathrm{~mL}$ fresh base oil. $5 \mathrm{~mL}$ oil samples are extracted every 20 minutes from the oil sample valve. The testing is conducted at steady-state conditions, see Tab. 4.
TABLE 3. APPROXIMATE INTAKE AIR COMP.

\begin{tabular}{|c|c|c|c|}
\hline Test Case (TC): & 1: & $2:$ & 3: \\
\hline Species: & \multicolumn{3}{|c|}{ Air Composition [mol/mol]: } \\
\hline $\mathrm{N}_{2}[\%]$ & 73.5 & 73.6 & 73.4 \\
\hline $\mathrm{O}_{2}[\%]$ & 19.7 & 19.6 & 19.7 \\
\hline $\mathrm{H}_{2} \mathrm{O}[\%]$ & 5.87 & 5.72 & 6.06 \\
\hline $\mathrm{H}_{2} \mathrm{SO}_{4}[\mathrm{ppm}]$ & 0 & 14.9 & 31.5 \\
\hline
\end{tabular}

TABLE 4. STEADY-STATE CONDITIONS FOR TESTING.

\begin{tabular}{lc}
\hline Parameter: & Value: \\
\hline Cylinder Liner Temperature & $100{ }^{\circ} \mathrm{C}$ \\
Charge Temperature & $160-190{ }^{\circ} \mathrm{C}$ \\
Lube Oil Temperature & $65-75^{\circ} \mathrm{C}$ \\
Charge Pressure & $1.15 \mathrm{bar}$ \\
Intake Air Flow & $50 \mathrm{~L} / \mathrm{min}$ \\
Mass Flow of Dosed Liquid & $143-169 \mathrm{~g} / \mathrm{h}$ \\
Engine Speed & $98 \mathrm{rpm}$ \\
Test Duration & $5-6 \mathrm{~h}$ \\
\hline
\end{tabular}

\section{ACID DEW POINT AND CONDENSATION}

The first law of thermodynamics combined with the charge air conditions for TC2 (Tab. 3) and engine geometry (Tab. 1) are used for calculating the cylinder gas pressure (compensated for heat loss) during compression and expansion. At TDC the calcu-

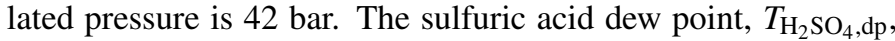
of the cylinder gas is coupled empirically to the partial pressures of $\mathrm{H}_{2} \mathrm{O}$ and $\mathrm{H}_{2} \mathrm{SO}_{4}\left(p_{\mathrm{H}_{2} \mathrm{O}}, p_{\mathrm{H}_{2} \mathrm{SO}_{4}}\right)$ [15] that are provided by the cylinder gas pressure trace and charge gas composition. This relation (Eq. (1)) is well documented and has been used extensively for modelling sulfuric acid dew points in power plants.

$$
\begin{array}{r}
\frac{1}{T_{\mathrm{H}_{2} \mathrm{SO}_{4}, \mathrm{dp}}}=2276 \cdot 10^{-6}-2943 \cdot 10^{-8} \ln p_{\mathrm{H}_{2} \mathrm{O}} \\
-858 \cdot 10^{-7} \ln p_{\mathrm{H}_{2} \mathrm{SO}_{4}} \\
+620 \cdot 10^{-8}\left(\ln p_{\mathrm{H}_{2} \mathrm{O}}\right)\left(\ln p_{\mathrm{H}_{2} \mathrm{O}}\right)
\end{array}
$$

Sulfuric acid (including water) may condense on the cylinder liner when the surface temperature is lower than the sulfuric 


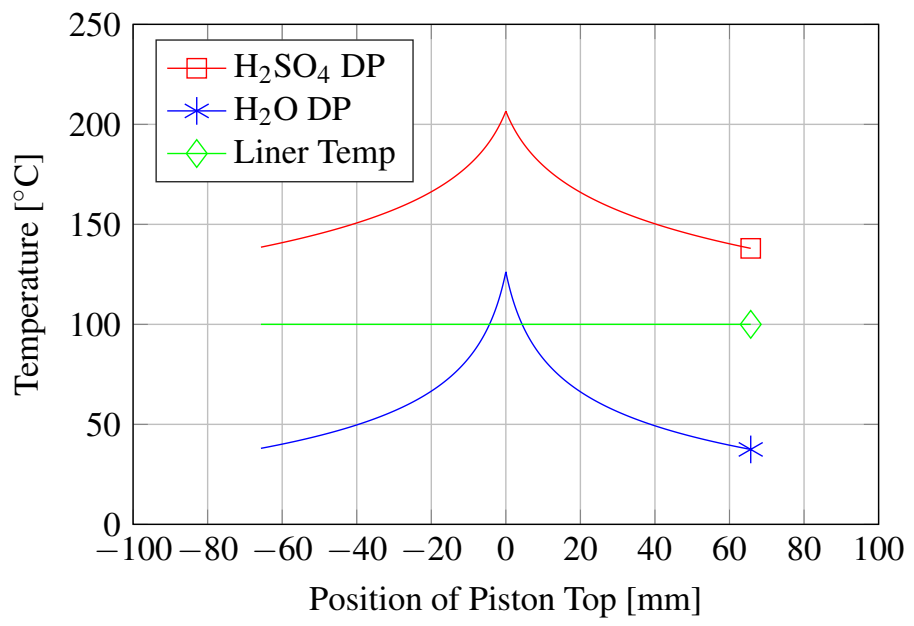

FIGURE 5. LINER TEMPERATURE WITH MODELLED DEW POINT TEMPERATURES IN CYLINDER GAS FOR TC2.

acid dew point. The sulfuric acid dew point temperature for TC2 between IVC and EVO (closed cylinder) are plotted relative to the position of the piston top, see Fig. 5.

At TDC the piston top is positioned at $0 \mathrm{~mm}$. The measured liner temperature in the top, middle and bottom varies between 98-100 ${ }^{\circ} \mathrm{C}$. Therefore the liner temperature is reasonably plotted as $100{ }^{\circ} \mathrm{C}$ over the full stroke as shown in the figure. The $\mathrm{H}_{2} \mathrm{SO}_{4}$ dew point generally exceeds the liner temperature and condensation of acid may occur continuously on the exposed liner surface. Yet, most acid is expected to condense in the top of the liner as this part is exposed to the highest $\mathrm{H}_{2} \mathrm{SO}_{4}$ pressures (when the piston is close to TDC). Furthermore, the liner top is exposed to the trapped cylinder gas for the longest period of time. This is in good agreement with marine engines running at low load $[12,16]$. Here cold corrosion is more pronounced near TDC.

\section{RESULTS AND DISCUSSION}

All values of iron and sulfur concentrations are taken directly from the XRF analysis and in units of $\mathrm{mg} / \mathrm{kg}$ equivalent to ppm.

In Fig. 6 a total of 19 oil sample vials from TC3 can be observed. When observing the vials lined up a darker yellow shade in the oil is observed over time, indicating sulfur, iron and other compounds accumulates in the oil. The pistons are fabricated in aluminium, however no $\mathrm{Al}$ is detected in oil samples. In addition visual inspection show no sign of corrosion of pistons, which also indicates that sulfuric acid condense on the pistons. This makes sense as temperatures above piston top reach approximately $900{ }^{\circ} \mathrm{C}$ during compression.
TC1 - Ensuring Engine is Run In The engine for the study was new from factory. A "running in" period is required before experiments are carried out as machined surfaces of moving engine parts (with non-matching surface roughness) are exposed to abrasion in the primary phase of engine use. Abraded iron will end up in the lube oil and disturb the analysis of corroded iron in the oil samples. E.g. operation with an oil pump failure during the preliminary preparation of the engine caused a serious accumulation of iron in the lube oil. Visual inspection of an extracted oil sample showed clear sign of black discoloration caused by abraded iron. An XRF measurement revealed 440.7 $\mathrm{mg} / \mathrm{kg}$ in the oil. The base run TC1 (Tab. 3) is performed after the engine had motored at $98 \mathrm{rpm}$ approximately 75 hours in the laboratory. Fig. 7 shows the evolution of Fe in the lube oil for $\mathrm{TC} 1$ and $\mathrm{TC} 1(2)$ that is yet a base run conducted after having performed TC2 and TC3.

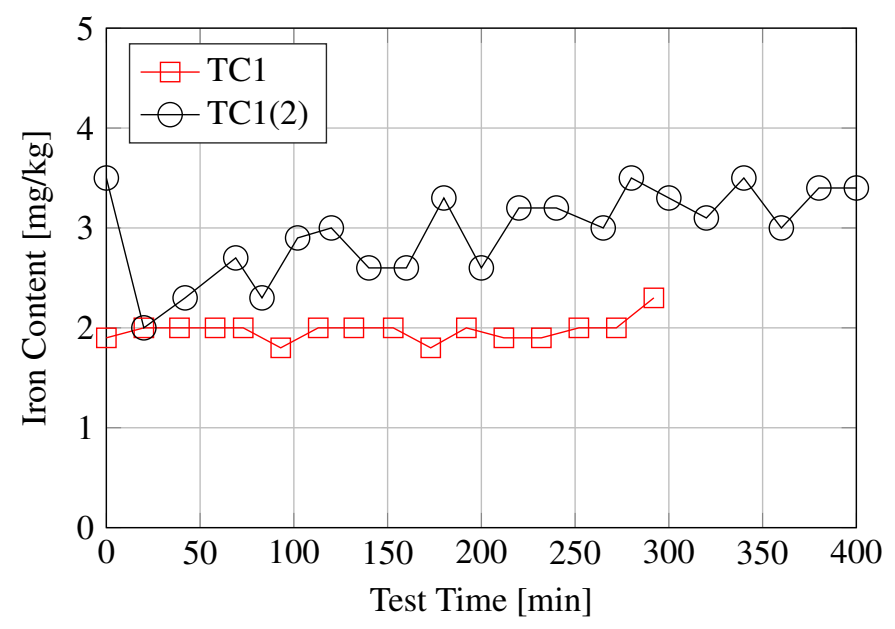

FIGURE 7. FE-CONTENT IN LUBE OIL FOR TC1 AND TC1(2).

The result of TC1 show that no iron accumulates during the five hour test period. It should be noted, however, that the ED$\mathrm{XRF}$ is not capable of detecting $\mathrm{Fe}$ in oil samples at concentrations much below $2 \mathrm{mg} / \mathrm{kg}$. Still, the result indicates that the moving parts are well lubricated. TC1(2) shows a similar trend, though, an iron accumulation of $1.5 \mathrm{mg} / \mathrm{kg}$ during a six hour test is observed. The first point in TC1(2) is a result of some leftover oil in the tubing from a previous test series and should therefore be disregarded. The difference between the Fe-traces of TC1 and TC1(2) could be explained by "wash out" of leftover iron from TC3 which is supported by the stagnating Fe-trace in TC1(2) after approximately $200 \mathrm{~min}$.

TC2 and TC3 Two experiments with sulfuric acid in the intake air are carried out, TC2 and TC 3 (Tab. 3), to measure the 


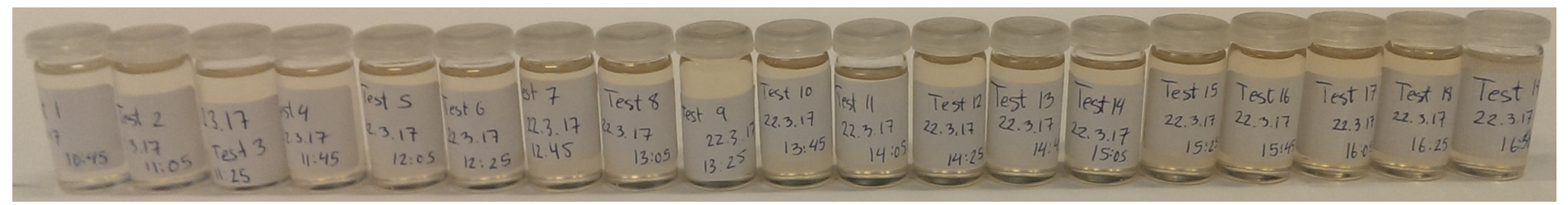

FIGURE 6. VISUALIZATION OF OIL SAMPLE CONTAMINATION IN TC3.

accumulation of elemental iron in the lube oil. As illustrated in Fig. 8 the iron content of the oil increases during the tests.

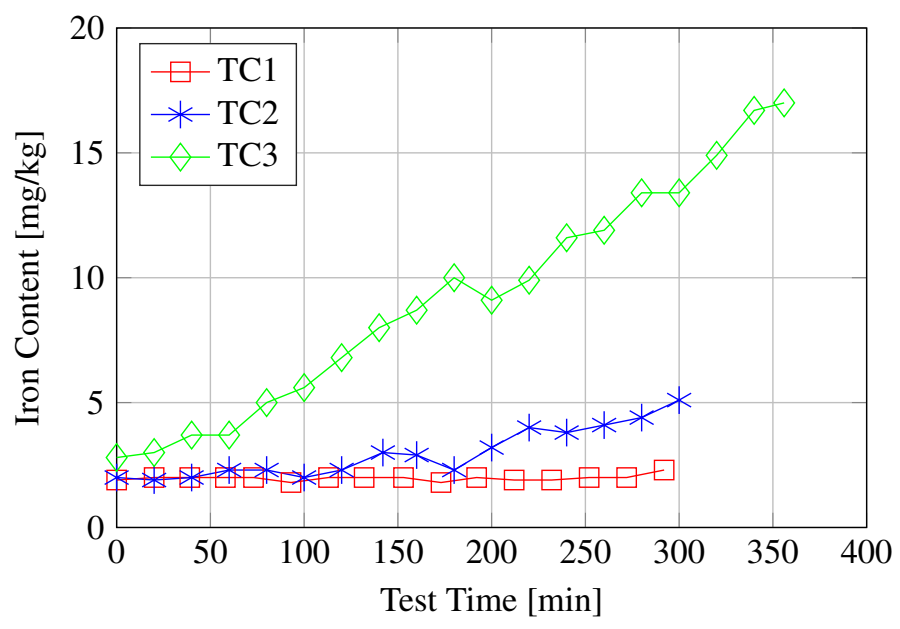

FIGURE 8. FE-CONTENT IN LUBE OIL FOR TC1, TC2 AND TC3.

The trend is that iron accumulates linearly in TC3. Yet, with a few outliers that may be explained by imperfect homogenization in the oil reservoir. This may also explain the "delay" of approximately 100 minutes in TC2. The accumulated iron of the non-corrosive test, TC1, is reintroduced in Fig. 8. The flat trace in TC1 tells that the accumulation in TC2 and TC3 is a result of corrosion. The higher corrosion rate in TC3 matches the higher $\mathrm{H}_{2} \mathrm{SO}_{4}$ concentration of the charge gas providing elevated $\mathrm{H}_{2} \mathrm{SO}_{4}$ partial pressures and thereby higher condensation rates on the cylinder liner during gas compression and expansion.

Investigating Two Similar Measurements The test conditions of TC3 was replicated as TC3(2) in order to verify the reproducibility of the results. Although the flow of diluted acid differed $2.4 \%$ from one test to the other the trend of accumulated iron shows a good agreement as seen in Fig. 9.

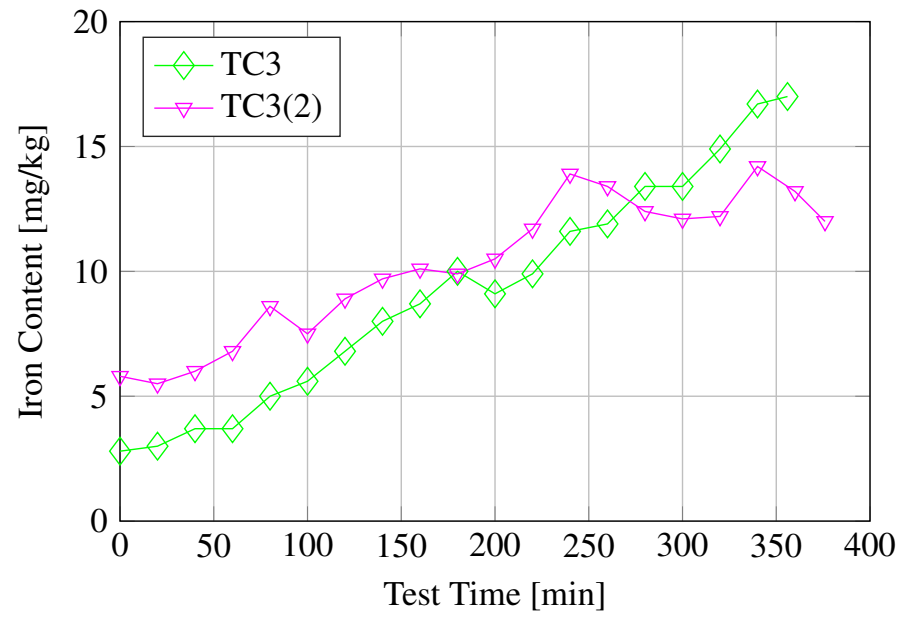

FIGURE 9. FE-CONTENT IN LUBE OIL FOR TC3 AND TC3(2).

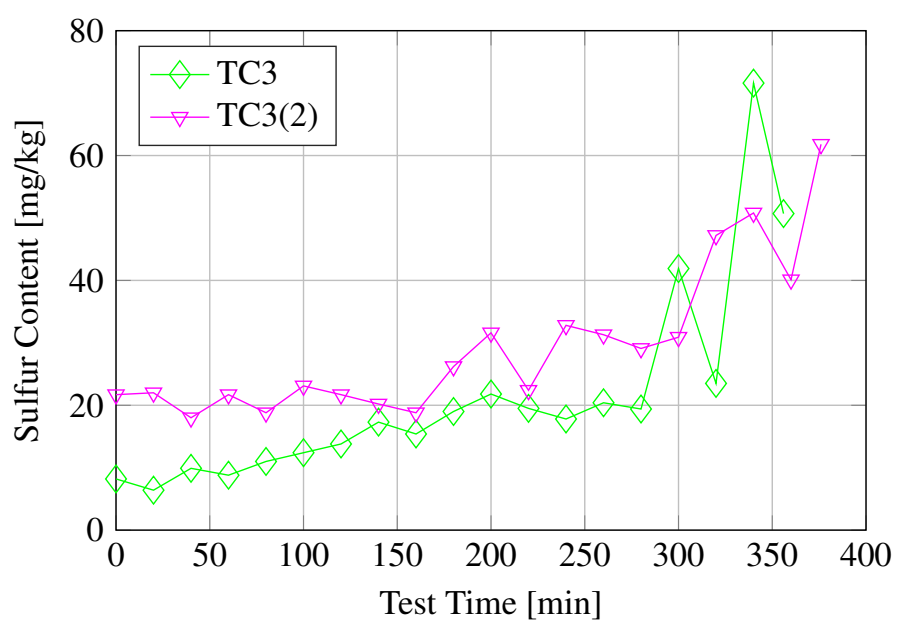

FIGURE 10. S-CONTENT IN LUBE OIL FOR TC3 AND TC3(2).

In Fig. 9 the higher starting point for iron in TC3(2) is likely due to leftover iron from a previous test as supported by the measured sulfur concentration presented in Fig. 10. The sulfur traces in Fig. 10 are similar although the initial sulfur concentration is higher in TC3(2) due to leftover sulfur from a prior experiment. 
Unlike the iron traces in Fig. 9 the gradients of the sulfur traces increase towards the end of the experiments where fluctuations are also observed. The trend is not fully understood but might be partly explained by a non-uniform distribution of condensed sulfur in the lube oil. Additional testing is required for verification. Nevertheless, based on the XRF measurements, it is carefully proposed that the condensation of $\mathrm{H}_{2} \mathrm{SO}_{4}$ exceeds the corroded iron by a factor of around 3 on mass basis.

\section{FUTURE WORK}

Preliminary investigations of cold corrosion are conducted on the engine test rig. The test rig makes it possible to run relatively short experiments where clear corrosion tendencies are observed. Future work will include several parameter studies, such as: Cylinder liner temperature, $\mathrm{H}_{2} \mathrm{O}$ - and $\mathrm{H}_{2} \mathrm{SO}_{4}$ - concentrations, engine speed, addition of other gas types $\left(\mathrm{SO}_{2}, \mathrm{CO}_{2}\right)$ for investigation of their corrosive properties. Furthermore lube oils with alkaline additives will be introduced.

Until now the difference in iron accumulation in TC1, TC2 and TC3 has only been explained by the addition of sulfuric acid. It has not been fully verified if it is corroded or abraded iron that is found in the extracted oil samples. Future work could include oil analysis using a Cold Corrosion Test Kit from Parker-Kittiwake. Corroded iron is characterized by being nonferromagnetic. Typical corrosion products are iron sulphate and hematite, where iron is in oxidation states +II and +III respectively. The test kit extracts + II-iron into an aqueous layer and the total corroded iron concentration is found using a colourimetric dye.

So far the sulfur species going into the engine is only accounted for using a gravimetric weight. Verification of sulfuric acid concentration in intake and exhaust gas could be made using Pentol $\mathrm{SO}_{3}$-equipment.

It is the intention that the sulfuric acid condensation rate from experiments can be used for developing lube oil strategies that hamper the cold corrosion occurring in marine diesel engines. When knowing the condensation rate at specific running conditions the amount of alkaline additives in order to neutralize the harmful acid can be assessed.

\section{CONCLUSION}

A novel experimental test facility involving a motored BUKH DV24 engine with a fixed liner temperature and known charge gas concentrations of $\mathrm{H}_{2} \mathrm{O}$ and $\mathrm{H}_{2} \mathrm{SO}_{4}$ is used for simulating cold corrosion of a cylinder liner in a large two-stroke marine diesel engine.

With a modified lube oil system the abrasive wear is found to be almost absent. The facility therefore makes it possible to distinguish between abrasive wear and corrosive wear that is measured (using XRF-technique) as accumulation of elemental iron in the lubrication oil (6-700 $\mathrm{mL}$ in total).
Corrosive wear rates are reproduced in near identical test cases and is found to correlate with the amount of $\mathrm{H}_{2} \mathrm{SO}_{4}$ in the charge gas. I.e. the condensing acid, that is measured as accumulated sulfur in the lube oil, increases due to higher partial pressures of $\mathrm{H}_{2} \mathrm{SO}_{4}$ in the cylinder gas.

\section{ACKNOWLEDGMENT}

The authors would like to thank the Innovation Fund Denmark for their contribution to the SULCOR project. The authors would also like to thank Research Engineer Svend Stensig Eskildsen from MAN Diesel \& Turbo for guidance and inputs regarding the work with the ED-XRF.

\section{NOMENCLATURE \\ ABDC After BDC \\ ATDC After TDC \\ BBDC Before BDC \\ BDC Bottom Dead Center \\ BTDC Before TDC \\ CAD Crank Angle Degree \\ EVC Exhaust Valve Closes \\ EVO Exhaust Valve Opens \\ IVC Intake Valve Closes \\ IVO Intake Valve Opens \\ TC Test Case \\ TDC Top Dead Center \\ $p \quad$ Partial pressure $[\mathrm{mmHg}]$ \\ $T$ Temperature [K]}

\section{REFERENCES}

[1] IMO. Sulphur Oxides (SOx) - Regulation 14.

[2] Cordtz, R. L., Schramm, J., and Rabe, R., 2013. "Investigating SO3 Formation from the Combustion of Heavy Fuel Oil in a Four-Stroke Medium Speed Test Engine”. Energy \& Fuels, 27(10), pp. 6279-6286.

[3] Engel, P. K., Thompson, R. E., and Silvestrini, R., 1979. "Corrosion and Fouling Potential in Diesel Exhausts". Journal of Engineering for Power, 101(4), pp. 598-606.

[4] Cordtz, R. L., Schramm, J., Andreasen, A., Eskildsen, S. S., and Mayer, S., 2013. "Modeling the Distribution of Sulfur Compounds in a Large Two Stroke Diesel Engine". Energy \& Fuels, 27(3), pp. 1652-1660.

[5] Reiner, T., and Arnold, F., 1994. "Laboratory investigations of gaseous sulfuric acid formation via $\mathrm{SO} 3+\mathrm{H} 2 \mathrm{O}+\mathrm{MH} 2 \mathrm{SO} 4+\mathrm{M}$ : Measurement of the rate constant and product identification". The Journal of Chemical Physics, 101(9), pp. 7399-7407.

[6] Cordtz, R. L., Mayer, S., Schramm, J., and Eskildsen, S. S., 2014. "Characteristics of Sulfuric Acid Condensation 
on Cylinder Liners of Large Two-Stroke Marine Engines". 3. Rostocker Großmotorentagung - 3. Rostocker Großmotorentagung - 2014.

[7] Land, T., 1977. "The Theory of Acid Deposition and its Application to the Dew-Point Meter". Journal of the Institute of Fuel, 50(403), pp. 68-75.

[8] Dye, S., 2014. "Optimising Feed Rate in the Fight Against Cold Corrosion". Sea Technology, 55(10), pp. 55-56.

[9] Ciuti, B. Bidoli, M. Piazzesi, A., 1977. "Particular Operating Characteristics of Lubricants for Cylinders of Separately Lubricated Two-Stroke Diesel Engines". Lubrication Engineering, 33(2), p. 79.

[10] MAN Diesel \& Turbo, 2014. Service Experience MAN B\&W Two-stroke Engines. Tech. rep.

[11] Bovington, C. H., 2010. "Friction, Wear and the Role of Additives in Controlling Them". In Chemistry and Technology of Lubricants. Springer, pp. 77-105.

[12] Jakobsen, S. B., and Ueda, S., 2014. "Low Load Operation Issues and Cylinder Liner Cold Corrosion Control". Journal of the Japan Institute of Marine Engineering, 49(1), pp. 43-51.

[13] Maersk Fluid Technology A/S. Case Study: Cold Corrosion Prevention.

[14] NN, 2002. “'Intelligent' Cylinder Lubrication". Mermarine Engineers Review, pp. 33-34.

[15] Verhoff, F. H., and Banchero, T., 1974. "Predicting Dew Points of Flue Gases". Chemical Engineering Progress, 70(8), pp. 71-72.

[16] Weber, M., and Räss, K., 2016. "Interaction Between Ship Operation and Cylinder Lubrication of Marine Two-Stroke Diesel Engines". 28th CIMAC World Congress. 